
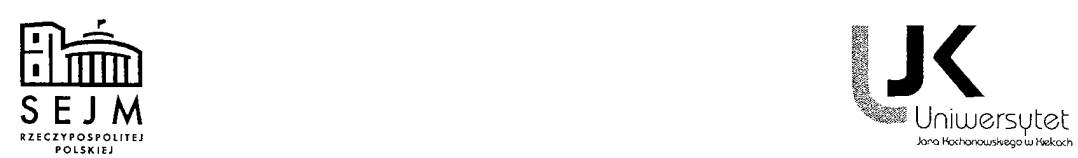

$3 k a$

stracji
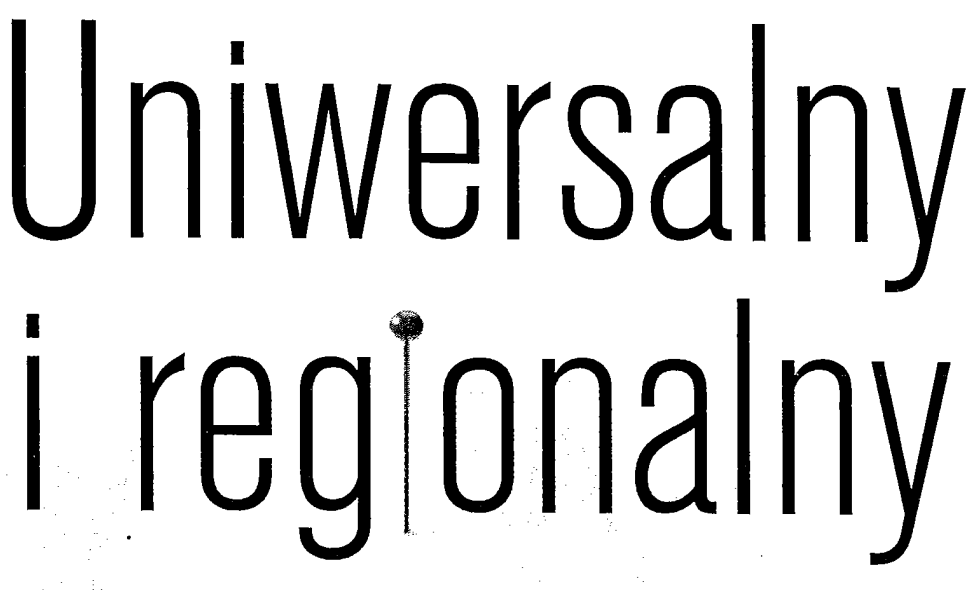

wymiar ochrony praw człowieka

Nowe wyzwania - nowe rozwazania

tom 3

Redakcja naukowa Jerzy Jaskiernia

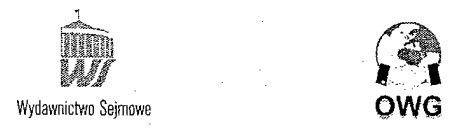




\section{International and Constitutional Approach of Business and Human Rights}

\section{Introduction}

Business and human rights [BHR] is seemingly a recent movement, however its roots can be found in the concept of Corporate Social Responsibility [CSR ${ }^{1}$. Thus it is not a completely new initiation, although still a recognised challenge since the late 1980 's. In the last decades a range of research projects, books and articles applying multidisciplinary approach were devoted to the topic. ${ }^{2}$ The main objective of BHR discussion is to expand somehow the (international) human rights obligations to multinational enterprises [MNEs], transnational companies [TNCs] and other business entities. It is more than the CSR as softly tries to create enforceable duties for companies beyond the self-regulation, and establish the grounds of their accountability for human rights violations. In constitutional legal terms it leads to the old question of third party effect of human rights on the one hand and extraterritorial jurisdiction of the national courts on the other. As a related problem, the constitutional background of the application of international law by the courts can also be mentioned.

To understand BHR, one can choose a top down approach, and analyse the actions and instruments of the United Nations and - at least in regional context - the followup actions of the European Union, which are to date of voluntary nature, and even not belong to the international soft law, but they may be assessed as a kind of policy. The other choice is the bottom up approach, from the side of the national feedbacks to the

* The publication was supported by the Bolyai János Research Scholarship of the Hungarian Academy of Science.

1 The term "corporate social responsibility" came into common use in the late 1960 s and early 1970s. CSR is a form of corporate self-regulation integrated into a business model. CSR policy functions as a built-in, selfregulating mechanism whereby a business monitors and ensures its active compliance with the spirit of the law, ethical standards, and international norms.

${ }^{2}$ See e.g. K.M. Leisinger, Business and human rights - In The Future of Sustainability, ed. Marco Kciner, Springer 2006, p. 117-151; R. Falk, Interpreting the Interaction of Global Markets and Human Rights, in Globalization and Human Rights, ed. Alison Brysk, Bcrkeley-Los Angeles-London 2002; M. Weschka, Human Rights and Multinational Enterprises, How Can Multinational Enterprises Be Held Responsible for Human Rights Violations Committed Abroad?, "Zeitschrift für ausländisches öffentliches Recht und Völkerrecht" 2006, № 66, p. 625-661; F. Wettstein, Multinational Corporations and Global Justice, Stanford, 2009; S. Joseph, Corporations and Transnational Human Rights Litigation, Oxford and Portland, 2004; J. Dine, Companies, International Trade and Human Rights, Cambridge 2007; The UN Guiding Principles on Business and Human Rights, Foundations and Implementation, ed. R. Mares, Boston 2012; J.G. Ruggie, Just Business. Multinational Corporations and Human Rights, New York-London 2013. See also Institute for Human Rights and Business; see: <http//www. ihrb.org $>$ and $<$ http//www.business-humanrights.org/Home $>$. 
international standards and the relation of international human rights and domestic fundamental rights obligations, determined by the constitutional design of the states.

Both of the mentioned approaches may be influenced by the concept of global constitutionalism, which accepts the convergence of national constitutional configurations in case of those states that share the same constitutional values, i.e. belong to the same constitutional families ${ }^{3}$. According to Law and Versteeg, this convergence is characterised by constitutional learning (i.e., in the course of attempting to learn from one another, countries are likely to imitate one another), constitutional competition (i.e., the need to attract and retain capital and skilled labor gives countries an incentive to offer similarly generous constitutional guarantees of personal and economic freedom), constitutional networks (i.e., reward countries for adopting the same type of constitutional regime that others have already adopted), and constitutional conformity (i.e., countries face pressures to conform to global constitutional norms in order to win acceptance and support $)^{4}$.

This article applies both the top down and bottom up approach and tries to evaluate the outcomes of the BHR policies and strategies in the light of global constitutionalism.

\section{Top down approach}

The core problem is how the individual's inviolable and unalienable fundamental rights can be guaranteed in a globalised community, if we presume that a kind of "world democracy" may come into existence. In other words, as Galgano formulated the question is how can the features of democracy, having developed within a national framework, be adapted to a post-state system of governance? ${ }^{5}$ Surely essential is the access to infective fundamental right protection with efficient remedies for the legitimisation of international law and international public order.

According to Tomuschat, the international community has attained the positive international protection of human rights in three theoretical and historical stages. The first step is reaching a consensus with respect to the necessity of protection and the scope of the and national adoption. The third stage is international codification, putting it into a treaty enforcement of rights. Fen the stage is establishing and operating a mechanism for the have, by and large, been taken universalist approach admits that whilst the first two steps - has not yet been accomplished' . In addition, the system of international protection has to global reality (handling system; it has to be continuously adjusted to the changing state of ics, economic and financial crime, flow of data, environmental disasters, pandem-

${ }^{3}$ D.S. Law, M. Versteeg, The Evolution and Ideology of Global Constitutionalism, Washington University in St. Louise, School of Law, "Faculty Research Paper Series" 2010, № 10-10-01, p. 7-10.

"Ibidem, p. 11-24

${ }^{5}$ F. Galgano, Globalizáció a jog tükrében [Globalisation through the prism of law], HVG-ORAC, Budapest
6 , p. 7, 9 . 006, p. 7,9

'Ch. Tomuschat, Human Rights, Between Realism and Idealism, Oxford 2003, p. 3. 
As the UN Human Rights High Commissioner formulates the phenomenon in respect of business, "The global developments over the past decades have seen non-state actors such as transnational corporations and other business entities play an increasingly important role both internationally, but also at the national and local levels. The growing reach and impact of business enterprises have given rise to a debate about the roles and responsibilities of such actors with regard to human rights. International human rights standards have traditionally been the responsibility of governments, aimed at regulating relations between the state and individuals" . In Ruggie's words, "The root cause of the business and human rights predicament today lies in the governance gaps created by globalization - between the scope and impact of economic forces and actors, and the capacity of societies to manage their adverse consequences. These governance gaps provide the permissive environment for wrongful acts by companies of all kinds without adequate sanctioning or reparation. How to narrow and ultimately bridge the gaps in relation to human rights is our fundamental challenge".

Many scholars pointed out that MNEs can infringe human rights directly or indirectly. The infringement is direct, if the enterprise uses child or forced labour, does not guarantee safety and health precautions, or establishes inhuman working conditions (like in sweatshops), discriminates on the bases of gender, race, sexual identity, belonging to ethnic, religious minority on the workplace, pollutes the environment, etc. Indirectly, typically during armed conflicts or by supporting autocratic or totalitarian regimes MNEs can be complicit in or benefit from human rights violations committed by host states?.

At the same time, it also worth to keep in mind that the increased economic development goes hand in hand with improvement in human rights; and the role of the MNEs (their investments and operation) is inevitable in this respect. They not only contribute to the socioeconomic welfare but promote the efficient exercise of civil and political rights as well ${ }^{10}$.

This dual effect shall be taken into consideration in constructing the international and constitutional legal instruments in the field of accountability of business enterprises for human rights.

\section{Assessment of UN instruments for responsible business}

With the increased role of corporate actors, nationally and internationally, the issue of business' impact on the enjoyment of human rights has been placed on the agenda of the United Nations. Over the past decade, the UN human rights machinery has been

\footnotetext{
${ }^{7}$ See: $<$ http//www.ohchr.org/EN/Issues/Business/Pages/BusinessIndex.aspx $>$.

${ }^{8} \mathrm{~J}$. Ruggie, Protect, Respect and Remedy - A Framework for Business and Human Rights, innovations spring 2008, v. 3, № 2, p. 189-212, see: <http//www.mitpressjournals.org/doi/pdf/10.1162/itgg>.

${ }^{9}$ M. Weschka, op.cit., p. 626-627; D. Weissbrodt, Business and Human Rights, "University of Cincinnati Law Review" 2005, v. 74, p. 57-58; K.M. Leisinger, op.cit., 117 ff.

${ }^{10}$ R. Falk, op.cit., p. 61 and W.H. Meyer, Human Rights and International Political Economy in Third World Nations, Multinational Corporations, Foreign Aid, and Repression, Westport 1998, p. 108.
} 


\section{8 / Nóra Chronowski}

considering the scope of business' human rights responsibilities and exploring ways for corporate actors to be accountable for the impact of their activities on human rights ${ }^{11}$.
For initiating universal ognise that the human rights treaties just provide for indirect humates it was necessary to recties of businesses. The first efforts to define direc indirect human rights responsibilimore or less unsuccessful, or too 'to direct responsibilities of companies were the drafts of the UN Commission soft, however good lessons to learn. Amongst these that tried to create a code of OECD Guidelines ${ }^{13}$ and ILO Tripartite companies from the $1970 \mathrm{~s}^{12}$, as well as the ness in their sphere of competence ${ }^{15}$.

The UN Global Compact objective of sustainable, stable - a voluntary framework for responsible business with the General Kofi Annan in 1999 and it binding values on general human rights lutied in 2000. It contains a set of legally non mental protection and - since 2004 - anticos of businesses, labour standards, environmoon introduced the instrument, "The Gorruption ${ }^{16}$. As UN Secretary-General Ban Kiversal principles and to partner with the Global Compact asks companies to embrace uniplatform for the UN to engage effectively with Nations. It has grown to become a critical feature of the Global Compact is that participaniontened global business"17. A unique

${ }^{11}$ Business a

EN/Issues/Business/Pages/Businessh - UN High Commissioner for Human Rights. See: <http//www.ohchr.org/ i2 See e.g. United

I.L.M 626 (1984).

13 The OECD

business conduct that 44 adhering of foreign direct investment - encourage their - representing all regions of the world and accounting for $85 \%$ were updated in 2011 for the fifth time since they were first observe wherever they operate. The Guidelines

daf/inv/mne/oecdguidelinesformultinationalenterprises.htm>.
${ }^{11}$ 'The lLO's

tion by the ILO Governing Body, of the Tripartite in its sphere of competence resulted, in 1977, in the adop prises and Social Policy (MNE Declaration). lang--en/index.htm>.

${ }^{15}$ D. Weissbrodt, op.cit., p. $62-63$

${ }^{16}$ The UN Global Compact asks

ence, a set of core values in the areas of humanies to embrace, support and enact, within their sphere of influHuman Rights, Principle 1, Businesses should suppor labour standards, the environment and anti-corruption, human rights; and Principle 2, make sure that they are respect the protection of internationally proclaimed ple 3, Businesses should uphold the freedom of association andicit in human rights abuses. Labour Princitive bargaining; Principle 4, the elimination of all forms of force effective recognition of the right to collective abolition of child labour; and Principle 6 , the elimins forced and compulsory labour; Principle 5, the effecoccupation. Environment Principle 7, Businesses should of discrimination in respect of employment and challenges; Principle 8, undertake initiatives to promote greater a precautionary approach to environmental encourage the development and diffusion of environmenteatly ental responsibility; and Principle 9 , ple 10, Businesses should work against corruption in

"See: <http//www.unglobalcompact.org/>. 
a whole, but specifically its leadership. However, its effect is limited because of the lack of clarity regarding the definitions and distinctions on the duties of businesses and states; furthermore there are neither clear standards for monitoring and evaluation of corporations' conduct, nor repercussions for failing to adhere to the principles ${ }^{18}$.

It is not accidental that there is no international convention on the basic human duties yet, as such an international obligation presumably would cause more damage than advantage to human rights law, providing governments with excuses to limit the exercise of human rights ${ }^{19}$. The human duties have fallen into two categories. The first category comprises "vertical" duties in the relation of the individual and the state, which might be enforced by the government. The second category comprises horizontal duties in relations of the individual with other members of the society. Vertical duties usually appear in national constitutions, however separately from constitutional rights, i.e. the exercise of the rights is independent from the fulfilment of the duties. Horizontal duties are usually not written into the constitution, as the constitution transforms these into vertical duties, as authorises the state to specify and enforce them, and thus intervene into the organic relations of the society. In 2003, the UN Sub-Commission on the Promotion and Protection of Human Rights - building upon the previous initiatives regarding corporate social responsibility - approved a draft declaration on human social responsibilities (i.e., corporate human rights duties), ${ }^{20}$ but finally the Human Rights Council [HRC] had not even considered the Norms. The draft was harshly criticised by the stakeholders because of its scope, vagueness, uncertain legal status and force, etc. As Arnold assessed, "the Norms fail to provide a plausible and defensible account of those duties and in so doing undermine, rather than enhance, efforts to ensure that corporations contribute to the fulfillment of those basic human rights necessary for a decent standard of living for all'21.

In 2005, John Ruggie, professor of Harvard University was appointed as a Special Representative to the Secretary-General of the United Nations [SRSG] with a mandate to investigate a number of important questions relating to the obligations of business for the realisation of fundamental rights. As Knox emphasized, that time the application of human rights law to corporations was highly contested: human rights groups [NGOs] and corporations differently approached whether corporations have, or should have, direct obligations under human rights $\operatorname{law}^{22}$. Bilchitz pointed out, that the man-

ix D. Weissbrodt, op.cit., p. 63; D.G. Arnold, Transnational Corporations and the Duty to Respect Basic Human Rights, "Busincss Ethics Quarterly" 2010, v. 20, № 3, p. 3-4. Available at SSRN, see: <http//ssrn.com/ abstract=1612296> and <http//www.unglobalcompact.org/About TheGC/index.html>.

"See J.H. Knox, Horizontal Human Rights Law, "The American Journal of International Law" 2008, № 1, p. $1-3$.

${ }^{20}$ Draft Norms on the Responsibilities of Transnational Corporations and Other Business Enterprises with Regard to Human Rights, E/CN.4/Sub.2/2003/12 (2003); see: <http//www1.umn.edu/humanrts/links/ NormsApril2003.html>.

${ }^{21}$ D.G. Arnold, op.cit., p. 9. See also K.M. Leisinger, op.cit., p. 2.

${ }^{22}$ J.H. Knox, The Ruggie Rules, Applying Human Rights Law to Corporations, in The UN Guiding Principles on Business and Human Rights, Foundations and Implementation, ed. R. Mares, Boston 2012, p. 51. Available also at: $<$ http//www.globalgovernancewatch.org/docLib/20110829_Ruggie_Rules.pdf $>$. 


\section{0 / Nóra Chronowski}

date of the SRSG arose from the failure by the HRC a year earlier to adopt the above mentioned Norms, as many of the states was on the opinion that BHR issues deserve provided with a broad mandate was initially appointed for a two year period and was The HRC endorsed unanimously Ruggined the terms of reference for his activities ${ }^{23}$ Mares assessed, "While the Norms choies reports, first in 2008 and finally in 2011. As to a large extent relying on international more direct path to corporate accountability, tions, the SRSG conceived a broader and treaties and monitoring, and national regulaing the responsibilities and roles of various centralised template aimed at leveragrationalities to move markets towards a more social actors and relying on legal and other

As a result of the SRSG's towards a more socially sustainable path"24.

and responsibilities of governments anere is now greater clarity about the respective roles human rights. Most prominently and business with regard to protection and respect for as a result of the UN "Protect, Respect anding understanding and consensus have come business, which was elabotect, Respect and Remedy" Framework on human rights and Guiding Principles on Business and SRSG. On 16 June 2011, the UN HRC endorsed Respect and Remedy" Framework (hereinan Rights for implementing the UN "Protect, time - a global standard for preventing and the Framework), providing - for the first human rights linked to business activity ${ }^{25}$ And addressing the risk of adverse impacts on ciples were issued to assist governments and ${ }^{2}$. Along with the Framework, also Guiding Prin-

The Framework rests on three plint and corporations in the implementation. human rights abuses by third parties, including is the state duty to protect against priate policies, regulation, and adjudication. The business enterprises, through approto respect human rights, which means that business is the corporate responsibility diligence to avoid infringing on the rights of others enterprises should act with due which they are involved. The third is the others and to address adverse impacts with tive remedy, both judicial and non-judicial. Each preater access by victims to effecinter-related and dynamic system of prevent Each pillar is an essential component in an to protect because it lies at the very core of the and remedial measures: the staty corporate responsibility to respect because ine international human rights regime; the ness in relation to human rights. and access to the basic expectation society has of busiefforts cannot prevent all abuse ${ }^{26}$.

${ }^{2.3}$ D. Bilchitz, The Ruggie Framework, An Adequate Rubric for Corporate Human Rights Obligations?, "SUR International Journal on Human Rights" 2010, v. 7, № I2, p. 199-201. See: <http//www.surjournal.org/eng/
conteudos/pdf/12/miolo.pdf>.

${ }^{2 .}$ R. Mares, Business and Human Rights After Ruggie, Foundations, the Art of Simplification and the Impera-
of Cumulative Progress, in The UN Guiding Principles on Business and Human Rights tive of Cumulative Progress, in The UN Guiding Principles on Business and Human Rights, Foundations and
Implementation, Boston 2012 .

${ }^{25}$ See: $<$ http//www.ohchrorg/EN/Issues/Business/Pages/BusinessIndex.aspx>.

and Remedy" Framework, Report of the Special Representative of rights and transnational corporations and other businentative of the Secretary-General on the issue of human 


\section{Actions of the EU for enhanced corporate social responsibility}

The European Commission adopted a new CSR strategy in 2011, and encourages enterprises to base their approach to corporate social responsibility on internationally recognised CSR guidelines and principles ${ }^{27}$. This is especially the case for larger enterprises and for enterprises seeking to adopt a more formal approach to CSR. For companies seeking a formal approach to CSR, especially large companies, authoritative guidance is provided by internationally recognised principles and guidelines, in particular the updated OECD Guidelines for Multinational Enterprises, the ten principles of the United Nations Global Compact, the ISO 26000 Guidance Standard on Social Responsibility, the ILO Tripartite Declaration of Principles Concerning Multinational Enterprises and Social Policy, and the United Nations Guiding Principles on Business and Human Rights. This core set of internationally recognised principles and guidelines represents an evolving and recently strengthened global framework for CSR. European policy to promote CSR should be made fully consistent with this framework. As Erkollar and Oberer evaluated the EU's CSR strategy: "The European Commission was a pioneer in developing a public policy to promote corporate social responsibility, defining in their 'European Alliance' (2006) the support of multistakeholder CSR initiatives, research and education on CSR, and the support of small and medium-sized companies in their CSR activities, as priority areas for the European Union to focus on, accompanied by an applicable legislation and collective agreements between social partners. With it's new strategy on CSR (2011) the European Commission emphasized the need for the establishment of sector-based platforms for enterprises and stakeholders to make commitments and jointly monitor progress, the improvement and tracking of levels of trust in businesses, the creation of guidelines for the development of future self- and co-regulation initiatives and the improvement of company disclosure of social and environmental information"28.

The BHR issues are involved into (or subordinated to) the broader CSR strategy at EU level and has to date no overarching character. The European Commission has published practical human rights guidance for enterprises in three business sectors (employment and recruitment agencies, oil and gas, information and communication technology). These guides are the outcome of an intensive multistakeholder process, and are consistent with the UN Guiding Principles on BHR. They take particular account of the experience of EU companies, but aim to be as globally applicable as possible. The guides are not intended to be legally binding ${ }^{29}$.

${ }_{27}$ European Commission, An Analysis of Policy References made by large EU Companies to Internationally Recognised CSR Guidelines and Principles, March 2013; sce: <http//ec.europa.eu/enterprise/policies/sustainable-business/files/csr/csr-guide-princ-2013_en.pdf>.

${ }_{28}$ A. Erkollar B.J Oberer, Responsible Business, The European Union is Driving Forward the European Strategies on Corporate Social Responsibility, "Journal of EU Research in Business" 2012. See: <http//www.ibimapublishing.com/journals/JEURB/2012/360374/360374.html>.

${ }^{29}$ See: <http//ec.europa.eu/enterprise/policies/sustainable-business/corporate-social-responsibility/humanrights/index_en.htm> 


\section{2 / Nóra Chronowski}

\section{Bottom up approach - constitutional feedbacks}

The system of international human rights protection may be criticized more harshly that beyond the trends of globalisation instrumentalist approach. It must keep in mind also "reverse globalisation" 30 , particularisation andism and constitutional convergence, can also be observed in the global world. Don and constitutional divergence processes ognised human rights create obligations fonnelly pointed out that internationally recupon states to account for their fulfilms for states, and international organisations call porary international practice it means: every state is authoright to $x$, in contemthe application and protection of the every state is authorized to and responsible for laration of Human Rights is the common to $x$ in its own territory. The Universal Decnations - and for the states representing themdard of achievements for all peoples and states and the international human rights obm. Covenants create obligations only for persons falling under their jurisdiction. Although hations of states exist only in relation to nationalized, their transposition has Although human rights legal norms have interporary international and regional human remained almost exclusively national. Contemmonitoring the relationship between states rights regimes are supervisory mechanisms the essentially state concept of hum states and individuals. They are not alternatives to (within the framework of the houman (fundamental) rights ${ }^{31}$. For example, in Europe [ECtHR] examines the relation Council of Europe) the European Court of Human Rights of subsidiarity. The position of the Inter-Am states and citizens or residents on the basis The central role of states in contemporamerican Court of Human Rights is the same $e^{32}$. indisputable with respect to the content international human rights structures is also ticipatory rights are typically (though not gecognized rights. The most important parobligations - e.g. in the area of education anerally) limited to citizens. There are several only with respect to residents and they an and social safety - which may be undertaken tion of the state. Foreign states do ney apply to aliens only if they fall under the jurisdicobligation, for instance, to protect victims an internationally recognized human right free to go beyond the means of persuasion in torture in another country. They are not temporary norms of sovereignty prohibit in the case of foreign victims of torture. Conagainst torture or any other human right states from applying means of coercion abroad

For the succes of the BHRan right violation ${ }^{33}$

soft law to date, it is necessary to concept, which does not even belong to the international

\footnotetext{
${ }^{30}$ For the

Bonnie Honig, Will Kymlicka,

3! I Donuell

Corporations Accountable for Human Rertcomings and Disadvantages of Existing Legal Mechanisms to Hold Multinational p. 403.

${ }^{3.3}$ J. Donnelly, Universal Human Rights in Theory and Practice, New York 2003.
} p. $281-306$. 
as - at least - secondary subjects of international law. From this perspective was the Ruggie Framework criticized by Bilchitz, because considering the limits of international human rights law enforcement, corporations should have binding obligations for the realisation of fundamental rights. Non-binding instruments - such as the Framework - do not assist in the development of customary international law in the area of BHR and may even hamper progress. Corporations should not only respect human rights, i.e. avoid their violation, but also actively contribute to the realisation of human rights (positive duties) ${ }^{34}$. Corporate accountability also cannot be effectively dealt with through existing methods; as Vega, Mehra and Wong stated, "While [the Framework and the Guiding Principles] contain positive elements, they fall short of creating an effective mechanism for addressing the many corporate human rights violations that continue by not providing a remedy in the international arena when national systems are unavailable or ineffective"35.

Even in the European Union, which has an intensively evolving fundamental rights framework $^{36}$, are significant obstacles that hamper the efficient application of the UN Framework for BHR. A conference on CSR was organised during the Swedish EU presidency in November 2009, where remarkable conclusions were drawn about the problems with the functioning of the UN Framework. In respect of the states' obligation to protect human rights, the incoherence of the Member States legislation (e.g. on issues of trade, investment, overseas development and corporate law) was seen as presenting a fairly uneven playing field within the Union of 27 states even before relations with other states, such as Brazil, Russia, India or China. The accountability mechanisms relating to the overseas operations of EU-domiciled companies was also mapped, and cited as an important first step in understanding some of the state-based gaps that might exist. In the field of corporate responsibility to respect, business requires states to play their appropriate role in order to help create additional demand. The issue of avoiding complicity in the human rights abuses perpetrated by others was also seen as being key feature here. As to the remedies, it was concluded that greater awareness of and adherence to existing international human rights mechanisms and greater access to effective remedies, both legal and non-legal is needed ${ }^{37}$.

It can be added that also the national constitutions and constitutional jurisprudence should be more open to consequences of the global world order by giving up the regulative and applicative models related to and rooted in the traditional concept of state sovereignty. In the following three major questions of constitutional design - the third

\footnotetext{
${ }^{34}$ D. Bilchitz, op.cit., p. 199.

${ }^{35}$ C. de la Vega, A. Mehra, A. Wong, Holding Businesses Accountable for Human Rights Violations - Recent Developments and Next Steps. Dialogue on Globalisation, 2011; see: <http//library.fes.de/pdf-files/iez/08264.pdf>.

${ }^{36} \mathrm{~N}$. Chronowski, Integration of European Human Rights Standard - the Accession of EU to the ECHR, [in:] Efektywność europejskiego systemu ochrony praw czlowieka, Toruń 2012, p. 957-975.

${ }^{37}$ Ministry for Foreign Affairs Sweden, Protect, Respect, Remedy - a Conference on Corporate Social Responsibility (CSR), Stockholm 10-11 November 2009, Conference Report, p. 5-8, available at: <http//www. ihrb.org/pdf/Protect_Respect_Remedy_Stockholn_Nov09_Conference_Report.pdf>.
} 
party effect, the application of international law and the extrateritorial jurisdiction of the courts - will be discussed which should re-evaluated extraterritorial jurisdiction of realisation of businesses' responsibility for human rights vion revisited for enhanced

\section{Third party effect (Drittwirkung)}

Constitutions of the democratic states

fundamental rights catalogue in line with fundall be normative and effective, i.e. enforceable befor human rights law. These rights rights stal rights can be vertical or horizontal. The vere the courts of law. The effect of als against them the historical function of the rights, whical effect of the fundamental law, as well as the organs and limit the public power ${ }^{38}$. Thich is to protect the individudamental rights human rights protection; and claims against the states to guarantee the effective funto protect the rights. vail also betweents. The horizontal effect of fundamental i.e. if the given state fails actors. This theory of indirizontal or third party effect can be direct the legal relations of private not applicablect horizontal effect, the fundamental rights indirect. ${ }^{39}$ According to the determining privectly in private law relations; it is only norm of the constitution is effect exists private law relations among individuals used as an interpretative guide to rights. It is the private law obligations are interpreted se. Thus, indirect horizontal investment, duty of the state, i.e. the legislator to crete with regard to fundamental rights so as the principles compliance with the constitutionale the rules of private (trade, equality, freed principles of the civil code to transmit the and also international human regulation in the privacy, etc.); and thus the courts of law of human rights (dignity, theory of direct light of the constitutional (and international interpret the private law constitution are horizontal effect represents that the fundamal human rights) values. The private or labour applicable in the private relations of the inental rights enshrined in the zontal effect implies contracts infringing fundamental rights are invals. This results that a claim based implies that an individual has, in his action rule of private rights disputes, ${ }^{41}$. This idea would however convert the private an otherwise applicable

the most

${ }^{3 *}$ J. Petrétei, Az alkotmányos demokrácia alupintezmenyei, Basic lnstiting Budapest-Pécs 2009

${ }^{39}$ E. Engle, Third Party Effect of Fundamental Rights (Drittirkung), "Institutions of Constitutional Democracy, p. $165-166$

10) J. Petrétei, op.cit., p. 441.

${ }^{4}$ O.O. Cherednychenk

mentarity? "Utrecht Law Review" $2007, v .3$, rights and private law

${ }^{42}$ J. Petrétei, op.cit., p. 441. 
widely used and followed concept in practice is the idea of the indirect horizontal effect of constitutional rights. Without contesting the concerns on the direct horizontal effect it must not born in mind that MNEs and TNCs are very special, powerful and influential private actors, thus with regard to their overwhelming dominance over the individuals and even the states the application of direct horizontal effect of fundamental rights would be reasonable to their relations.

\section{Application of international law by national courts}

The national constitutions usually contain provisions on international law and international community, reaffirming the acceptance and respect of internationally agreed values, amongst the international human rights norms. Thus these kinds of constitutional provisions preliminary commit and restrain the national governments for and by the common international values $^{43}$. However, the constitutional declaration in itself does not guarantee that the international human rights law is applied and enforced effectively in a given country, because the enforcement depends on and influenced by the way of implementation (monist or dualist approach), the level and effectiveness of protection of the relevant constitutional provisions (by constitutional court or courts of law with constitutional review powers) and the exact content of those provisions (e.g. they refer to international law in general, or distinguish the sources of international law, firmly express the rank of the international law in the domestic legal system etc.), and finally the general attitude of the courts of law to the application of international treaties, international courts' judgments, universal customary international law, peremptory norms (ius cogens) and general principles of law recognized by civilized nations. Or as Cram explained: "When considering the migration of human rights norms into the judicial sphere, two initial observations may be made. The first is that while some constitutions oblige national courts to engage with norms in international human rights law, the precise status that is given to these norms varies considerably from constitution to constitution. Second, by comparison with explicit constitutional references to international human rights laws, there is a conspicuous lack of any equivalent constitutional exhortation to give effect to / consider / take account of national human rights norms"44.

The judicial dialogue - i.e., considering and applying international and foreign court decisions, drawing the consequences of international courts' judgments by national courts - may support the international BHR principles as well. The question is whether the international and national courts do really have a dialogue, or they continue their parallel monologues? ${ }^{45}$

${ }^{13}$ T. Ginsburg, S. Chernykh, Z. Elkins, Commitment and Diffusion, Why Constitutions Incorporate International Law, "University of Illinois Law Review" 2008, p. 101-137; see: <http//works.bepress.com/zachary elkins/1>.

${ }^{11} \mathrm{I}$. Cram, Resort to foreign constitutional norms in domestic human rights jurisprudence with reference to terrorism cases, "Cambridge Law Journal" 2009, № 68(1), p. 119.

${ }^{15}$ N. Chronowski, E. Csatlós, Judicial Dialogue or National Monologue? - the International Law and Iun garian Courts, forthcoming "ELTE Law Journal" 2013 
Dialogue is when two (or more) participants in equal position, are seeking agreement by exchange of views, generally in order to achieve some joint outcome. The precondition of the dialogue is the near identical or similar position of the participants, which primarily occurs on the level of powers and influence, and from this perspective, assumes identical weight. The dialogue is actually a specific form of debate; therefore it shall be distinguished from the general discussion and consultation as well. As a specific form of the debate, some criteria may be outlined that characterise the dialogue and without this framework the parties would misunderstand each other. First, the dialogue assumes a common goal, or if you prefer, a common subject on which the dialogue is going on. The dialogue may never end in itself Second criterion is the commitment to the common goal. All the participants want to achieve the common goal, which is to eliminate or reduce the conflict, and the debate or the individual interests shall be subordinated to this goal. Regularity is also an important feature of the dialogue. The dialogue is rarely a single exchange of views, because the interests of the participants are usually complex. The fourth characteristic in a dialogue is that the parties strive to be conclusive and effective. All of them are interested in the conflict resolution, and therefore they are willing to "sacrifice", i.e., to give up some parts of their own interests in order to reach a mutual compromise outcome, because this is usually more preferable for everyone than enforcing their individual interests. Finally the mutuality must be mentioned, which should characterize all of the participants. The mutuality covers also concession, empathy, tolerance, etc. The meaning of a dialogue is not overcoming each other, but to achieve a common goal. A focal question is, whether and to what extent do the national courts consider the judgments of international or foreign courts. Do they just simply refer them, or do they reflect on them by overruling their own, former jurisprudence? The latter would prove the existence of judicial dialogue and contribute to the efficiency of international human rights law, the former, however, is not enough to satisfy the criteria of the dialogue.

Applying the general features of the dialogue to the courts, one can conclude that the basic condition - the equal position - is given if we consider the powers and status of e.g. the ECtHR, the constitutional courts and ordinary courts of last instance. As to the common goal and the commitment to that - first and second specific conditions - it may be supposed that the analyzed courts are to protect fundamental rights and common constitutional values, but these are very far and abstract common goals. The concrete goal of each court is to solve a given case, safeguard the ECHR or the constitution in line with its function, and the way they reach this goal is influenced by the circumstances of the given case, the references of the parties concerned, and the presumption of the judges regarding the racio decidendi. The latter also interferes with the regularity, because the national courts usually refer to international sources only if it supports the reasoning or has stronger convincing force than the purely domestic legal based argumentation. Fourthly, the courts have no conflict with each other, thus - although they respect each others statements and rulings - they need not to be conclusive and effective in this respect. Sometimes the domestic courts seem to be rather 
careful or reticent with the interpretation of international treaties as they maybe try to avoid a potential future conflict with the international court interpreting the given treaty authentically. Of course if all role-players - i.e. courts - agree that the conflict can be traced back to a given piece of domestic law infringing a normative international commitment, and the procedural conditions are available (their procedures were initiated, at least one of them has power to eliminate the concerned norm, they have appropriate procedural ties among each other), the international and domestic courts may cooperate effectively by referring each others' decisions. Finally, in the 'dialogue' of the courts, the mutual respect can be observed and rivalry is really rare phenomenon, but it is also true, that courts are not compelled to mutual concessions. Thus, as a final conclusion, it can be stated that the domestic courts apply the international law if they have to or they want to decorate their reasoning with it, but it is still far from a constructive dialogue, and organic inclusion of international law, principles and practices into the jurisprudence.

\section{The problem of extraterritoriality}

The problem of extraterritoriality related to the rule that international law holds states responsible for human rights violations, and not MNEs or TNCs. The states as duty bearers have to guarantee that business enterprises do not infringe the human rights in the territory where they operate. First and foremost the host state (where the MNE operates or the potential human rights violation occurs) should establish guarantees against the human rights violations by their national laws and law enforcement mechanism. However, because of the dominance and mobility of the MNEs, as well as the needs, means, economic interests or state of development of the given country, the offered human rights guarantees are often insufficient in the host state. E.g. it is very typical in developing countries that the governments fail to take actions against MNEs for human rights violations, because they need foreign investment, jobs, technical enterprise or they simply do not have resources (financials, legal procedures, non-corrupt judiciary, etc.) to sanction human rights abuses although would be willing to do so. ${ }^{46}$ For these reasons, it is a logical step on the side of the victims of human rights violations caused by MNEs that they - seeking for redress and compensation - try to sue corporations for their activities performed abroad in the home states, i.e. in the country where the given business enterprise is domiciled. Home States are not currently liable in international human rights law for failing to prevent, punish, or otherwise regulate the delinquencies of their TNCs' overseas operations, but the home states have high human rights records, developed procedures, non-corrupt and functioning court system, and international law also "recognises the right of home states to exercise extraterritorial jurisdiction over their nationals committing wrongs

\footnotetext{
${ }^{16}$ M. Weschka, op.cit., p. 628-629; S. Joseph, op.cit. p. 9-10; N.Z. Tévar, op.cit., p. 399-401.
} 
abroad". 47 Thus the national courts have the chance to rule on MNEs' overseas human
rights abuses, and enforce human filed mainly in common law coun rights norms "horizontally". Numerous suits were and United Kingdom courts against parentore United States, Canadian, Australian instrument for transnational human rights litigation ${ }^{48}$. The most successful legal US Alien Tort Statute (ATS) 1789 that litigation seemed to be undoubtedly the before lawyers began creatively using it in been dormant for nearly two centuries rights cases in US courts. The ATS grants the 1980s to bring international human claims by aliens alleging violations of the "lurisdiction to federal courts to hear tort itself cannot help to solve the problem of law of the nations" 49 . However, the ATS in several features into consideration in of liability of the MNEs, because courts take doctrine of separation of powers, the respect of transnational litigation, such as the ereign immunity and international comity action doctrine, the political question, sovas "forum non conveniens" 50 . In the recen considerations, the "corporate veil" as well greatly restricted the scope of ATS and limt landmark Kiobel decision the US courts human rights cases $^{51}$. US Court of Appeal for the US courts jurisdiction in foreign is inapplicable to corporations becul the ATS customary international law. The Supreme Courte liability is not a discernible norm of Alien Tort Statute could apply to corporat Court heard arguments over whether the sider whether the law could be invoked intions, and later expanded the case to confinally was controlled by the "presum in similar cases against anyone. The judgment that the Congress is presumed not to inten against extraterritoriality", which means it provides a "clear indication" of the relevant conduct occurred within. However, so long as at least some portion Altogether, this decision makes it far min the US, ATS cases may still be sustainable. sue US corporations based on the corpore difficult for the human rights activists to

${ }^{17}$ M. Weschka, op.cil., p. 629; S. Joseph, op.cit., p. 11-12

${ }^{18}$ S. Joseph, op.cit., p. 15; O. De Schutter, Transnational

Global Law Working Paper 01/05, Symposium - Transnational Corporations and Human Rights, An Introduction, of Law 7.

${ }^{49}$ N.Z. Tévar, op.cit., p. 408; S. Joseph, op.cit., p. 10, 17.

${ }^{50}$ M. Weschka, op.cil., p. 629-631; N.Z. Tévar, op.cit., p. 409

${ }^{5}$ Kiobel v. Royal Dutch Petroleum Co., Decided April 17,20

in the United States, filed suit in federal court under the Alien 2013. Petitioners, Nigerian nationals residing Dutch, British, and Nigerian corporations - aided and Alien Tort Statute, alleging that respondents - certain tions of the law of nations in Nigeria. The ATS provides the "ft]he Nigerian Government in committing violation of any civil action by an alien for a tort only " $t$ ]he district courts shall have original jurisdicUnited States". 28 U.S.C. $\$ 1350$. The District Court committed in violation of the law of nations or a treaty of the appeal, the Second Circuit dismissed the entict dismissed several of petitioners' claims, but on interlocutory corporate liability.

${ }^{52}$ Rich Samp

Litigation; see: <http//www.forbes.com/sites/wlf/2013/04/18/sul Dutch Petroleum \& the Future of Alien Tort petroleum-the-future-of-alien-tort-litigation/>. 


\section{Conclusions}

To sum up, BHR is still a policy instead of a legal framework, although by further development a really efficient instrument could it be as response to the challenges of globalisation on human rights. The limits of the United Nations' BHR concept are on the one hand the deficiencies of international human rights enforcement mechanisms, and on the other hand some constitutional dogmas on direct third party effect of human rights, the rigid and unimaginative application of international law by national courts, and excluding extraterritorial jurisdiction in human rights cases. Thus, for the success of "principled pragmatism" 53 of UN BHR Framework and policy, some paradigms of national constitutional law should be changed, or at least the domestic courts should make a better use of the constitutional convergence.

\footnotetext{
${ }^{53}$ For the term, see 'Just Business' - Ruggie on Business and Human Rights at the UN; see: <http//businesshumanrightsireland. wordpress.com/2013/05/13/just-business-ruggie-on-business-and-human-rights-at-the-un/>.
} 